\title{
Review
}

\section{Multicultural immunisation: Liberalism and Esposito}

\author{
Alexej Ulbricht \\ Edinburgh University Press, Edinburgh, 2015, v+209pp., ISBN: 978-0748695393
}

Contemporary Political Theory (2016) 15, e7-e10. doi:10.1057/cpt.2016.21;

published online 24 May 2016

This book faults liberal multiculturalism for being more committed to liberalism than to accommodating cultural difference and seeks to indicate what a 'true multiculturalism' would look like. Heavy on critique, it is light in developing the promised alternative. The analysis is pitched almost entirely at the level of theory. Real-world cases are assiduously avoided, whether minority cultural claims and controversies or multicultural policies in particular countries.

It is not surprising, of course, that liberal multiculturalism privileges liberal democratic values and institutions. For liberal multiculturalists, this is the very point of the exercise in trying to make liberal democracy more responsive to cultural diversity. Meanwhile, critics have been highlighting the Western-cum-liberal limits of so-called multiculturalism for decades - although more often they've been academics from the ranks of cultural studies, anthropology and sociology than cultural minorities themselves, it has to be said. Alexej Ulbricht's point of difference is that liberalism and its multiculturalist qualifiers invariably betray an 'immunitary logic', a term borrowed from the Italian philosopher Roberto Esposito. According to this logic, liberals include some modest cultural difference only in order to protect and fortify liberalism from the kinds of genuine cultural differences that inhabit the world.

A chapter each is devoted to critiquing three common liberal approaches to cultural accommodation - rights, consensus and recognition - in terms of their putative immunitary logic in protecting liberalism. These approaches are illustrated, respectively, by the work of Will Kymlicka, Bhikhu Parekh and Charles Taylor. For example, Kymlicka's theory of differentiated rights and citizenship is criticised for sanctioning only some minority cultural practices while excluding others deemed incompatible with liberal individualism. Parekh's intercultural dialogue is criticised for relying on a preset procedure that is not itself 'multiculturalised' and where the majority culture is privileged in being the final arbiter of disputes involving minority practices. Taylor's recognition model seems to be superior in emphasising respect of difference and identity. However, Taylor's model rests on the non-negotiability of 
'fundamental rights' even as it challenges cultural uniformity, thus excluding some cultural practices from the outset. The politics of recognition, Ulbricht concludes, is little different from liberal toleration in forbearing some modest diversity while ruling much difference out of order.

It is unclear what Ulbricht intends the concept of 'immunisation' as applied to liberal multiculturalism to amount to exactly. In biology, the immune system generally operates as a health preserving mechanism. Ulbricht uses the term as a kind of pathology. There is, he says, 'an Other-hostile tendency at the heart of liberal multiculturalism' (p. 12). He refers to 'immunisation' as a metaphor for describing liberalism's response to difference, yet he also deploys it as an explanatory concept. Thus, he suggests that liberalism is congenitally unable to get beyond its immunitary response to human difference, and so any 'true multiculturalism' needs to move beyond liberalism. A problem here is that the concept is used without discipline or boundaries. Ulbricht finds immunitary logic at every turn. If a democracy does not accept immigrants from certain backgrounds, then immunitisation is at work, and if it does accept them, then immunisation is also at work, since incorporating a small amount of a pathogen helps protect against the worst of it. The concept is applied in a classic illustration of non-falsifiability. Examining a wider range of liberal multiculturalist approaches might also have given Ulbricht pause. For example, the tolerationbased liberalism of Kukathas (2003) - which Ulbricht cites but does not discuss shows little sign of the claimed immunitary reflex.

The critical chapters are uneven. The chapter on consensus closely examines Parekh's intercultural dialogue approach and is the most effective. Ulbricht's observations on how the ideas of Gadamer and Habermas figure in Parekh's argument are insightful. In contrast, the chapter on recognition contains some howlers. It relies heavily on the American anthropologist Elizabeth Povinelli's (2002) 'cunning of recognition' thesis as developed in relation to the treatment of Aborigines under Australian multiculturalism: that liberal law both demands cultural authenticity and is repulsed by it. Ulbricht levels this thesis against Taylor's argument. Taylor, however, does not advocate cultural authenticity but rather the authenticity of identity, both individual and collective, which is a very different thing. Ulbricht also uncritically accepts Povinelli's essentialising take on the Australian case such that her mistakes become his. In Australia, multiculturalism has very little to do officially or in practice with policy on or the treatment of Aborigines. The insistence, in native title law, on Indigenous claimants demonstrating a continuous association with tribal lands, reflects an attempt to balance competing interests and to guard against spurious claims.

The main problem with Ulbricht's critique of liberal multiculturalism is that it reduces political philosophy to a crude sociology. No attempt is made to confront the normative arguments on which liberal approaches turn. Ulbricht declares in passing that he does not mean to defend practices such as sati, female genital mutilation and 
the like (p. 129). However, by not considering actual practices and cases the discussion is denied meaningful context for assessing liberal qualms.

The book's penultimate chapter and conclusion are devoted to outlining Ulbricht's vision of what a multiculturalism that escapes liberalism's 'immunitary paradigm' might look like. He contends that a 'true multiculturalism' must move beyond the language of rights, cannot be universal in aspiration and cannot operate according to the mode of toleration. It must eschew a totalising picture of the world in favour of seeing it as constituted by incommensurabilities. And it will be about promoting conviviality, which requires 'the thinking of new communal ontologies' (p. 146). Here, Ulbricht suggests 'the city and music as a model for a new politics of multiculturalism' (p. 154). The city, because it is a site of diversity, dissensus and interaction without domination. Music - or, more exactly, rhythm - because it allows for a relation of 'co-appearance as syncopation rather than as fusion' or harmony (p. 160).

Ulbricht offers a few examples of syncopated community. One entails an elderly South-East Asian woman spontaneously joining a white British hipster girl in doing tricks with the latter's hula hoop while waiting for a train, before going their separate ways. His gloss is that the episode, which he personally witnessed, reflects a moment of community where no order was imposed and the parties engaged on equal terms. Ulbricht also cites the everyday diversity in the London borough of Camden, where he once lived. Conceding that Camden's conviviality 'may not include a substantive liking' among the various groups, he insists 'there is more togetherness and lived coexistence, more multiculturality, here than in any party policy document on community relations' (p. 181).

After setting such a high bar with his trenchant criticisms of liberal multiculturalism, Ulbricht's gestures to an alternative come as a disappointment. There is, I think, something to be said for the idea of syncopation instead of fusion or harmony, although people who live in close proximity over time tend to be changed by the experience and develop some kind of hybrid identity. Ulbricht's everyday examples of syncopated community take place within the context of a liberal political order, as he notes. Yet, he gives no thought to how the interactions he observes may be facilitated and informed by the background conditions and presuppositions of liberal rights and citizenship. That Camden should have more multiculturality than policy documents on community relations is hardly surprising, since it is a place where people live and not a document. However, it may not be the kind of place it is were it not for policies guiding local government. Ulbricht's vision is almost naively apolitical.

An interesting aspect of the book is Ulbricht's account of Esposito's etymological retrieval of the word 'community'. Whereas liberal philosophy understands it in terms of subjectivity and property, as something one belongs to or that is held in common, its Latin roots convey a relation of mutual obligation that interrupts the identity of subjects and makes them no longer individual subjects' (p. 49). This is an arresting notion. Developed in Chapter 3, regrettably, it then disappears from view until the last chapter, where Ulbricht associates it with his vision of "polyrhythmic 
syncopation' (p. 180). Only it is not at all clear how mutual obligation gels with people and groups all jiving to their own beat.

Certainly, music - what Handel called the 'source of all gladness' - would better be served if sentences such as this one were banished from the city: 'In fact, the abject is not so much the object of the phobic as it is a case of symbolicity being cathected by a drive that is not object-oriented' (p.56).

\section{References}

Kukathas, C. (2003) The Liberal Archipelago: A Theory of Diversity and Freedom. Oxford: Oxford University Press.

Povinelli, E.A. (2002) The Cunning of Recognition: Indigenous Alterities and the Making of Australian Multiculturalism. Durham, NC: Duke University Press.

Geoffrey Brahm Levey

University of New South Wales, Sydney NSW 2052, Australia

g.levey@unsw.edu.au 